\author{
Available online at http:// bajas.edu.iq \\ https://doi.org/10.37077/25200860.2019.256 \\ College of Agriculture, University of Basrah
}

Basrah Journal

of Agricultural

Sciences

ISSN $1814-5868$

Basrah J. Agric. Sci., 32(Spec. Issue 2): 45-62, 2019

E-ISSN: 2520-0860

\title{
Checklists of Species of Ancylodiscoidid and Ancyrocephalid Monogeneans from Fishes of Iraq
}

\author{
Furhan T. Mhaisen ${ }^{*}$ \& Kefah N. Abdul-Ameer ${ }^{2}$ \\ ${ }^{1}$ Tegnervägen 6B, Katrineholm 641 36, Sweden \\ ${ }^{2}$ Department of Biology, College of Education (Ibn Al-Haitham), University of Baghdad, Baghdad, \\ Iraq \\ *Corresponding author e-mail: mhaisenft@yahoo.co.uk \\ Received 9 October 2019; Accepted 2 December 2019; Available online 1 November 2019
}

\begin{abstract}
Surveying 59 references concerning the occurrence of the monogeneans of the families Ancylodiscoididae and Ancyrocephalidae parasitizing fishes of Iraq showed the occurrence of 11 taxa of the family Ancylodiscoididae (genera Ancylodiscoides, Bychowskyella, Chauhanellus, Hamatopeduncularia and Thaparocleidus) and 19 taxa of the family Ancyrocephalidae (genera Ancyrocephalus, Cichlidogyrus, Cleidodiscus, Haliotrema, Ligophorus and Mastacembelocleidus). These monogeneans were reported from 19 valid fish host species in Iraq. Apart from five parasite species which were recorded from marine habitats (Ancyrocephalus sp., Chauhanellus australis, Haliotrema mugilis, Hamatopeduncularia sp. and Ligophorus mugilinus), the remaining parasite species were recorded from freshwater habitats. Among the infected fishes with these parasites, the Tigris catfish Silurus triostegus was infected with the highest number of parasite species (11 species), the mugilid fishes (Planiliza abu and P. subviridis) were infected with eight and seven parasite species, respectively, while 11 fish species were infected with only one parasite species each. Among the parasite species, Thaparocleidus vistulensis was reported from nine fish host species, while 22 parasite species were reported from one host species each. So far, eight synonymous names were applied for seven valid names of parasites of these two families in Iraq.
\end{abstract}

Keywords: Ancylodiscoididae, Ancyrocephalidae, Monogenea, Fishes, Iraq.

\section{Introduction}

The class Monogenea (previously used to be small worms that parasitize aquatic animals such as fishes and frogs. One of the most exciting things about this group of animals is the large number of species that exist (MonoDb, 2019). This group is also known as the Monogenoidea and the naming of the
Monogenea/ Monogenoidea remains confusing, partly because there is no clear answer to the problem as indicated in the historical account given by MonoDb (2019). The class Monogenea includes 5567 species belonging to 62 families of which the family Ancylodiscoididae includes 417 species and 
Mhaisen \& Abdul-Ameer/ Basrah J. Agric. Sci., 32(Spec. Issue 2): 45-62, 2019

the family Ancyrocephalidae includes 1349 species (GBIF, 2019). According to a personal communication between the first author of the present article (FTM) and Dr. David I. Gibson of the British Museum (Natural History) on 15 September 2019, the classification of monogeneans is 'up in air', waiting on molecular biologists to sort it out.

According to their attachment organs that are found in the posterior part of their bodies (haptor), monogeneans are divided into two subclasses: Monopisthocotylea which are provided either with hooks and hooklets and Polyopisthocotylea which are provided with clamps (Gusev, 1985). These two subclasses can be thought as hookers and clampers (MonoDb, 2019).) According to Pugachev et al. (2009), who considered the name as Monogenoidea, these two subclasses are considered as Polyonchoinea and Oligonchoinea, respectively.

In Iraq, Herzog (1969) published the first article on fish parasites, but that article included no mention of any monogeneans. Fattohy (1975) described the first monogenean from fishes of Iraq which was Paradiplozoon kasimii (as Diplozoon kasimii). Later on, many researchers detected different monogeneans from fishes of Iraq which now reach a total of 239 species, constituting $28.8 \%$ of the total items of the parasitic fauna of fishes of Iraq (Mhaisen, 2019). Among the ancylodiscoidids, AbdulAmeer (1989) was the first one to report on this group as she described Thaparocleidus vistulensis (as Ancylodiscoides vistulensis). Among the ancyrocephalids, Al-Daraji (1995) was the first one to report on this group as he recorded Ancyrocephalus sp., Haliotrema mugilis and Ligophorus mugilinus (as Haliotrema mugilinus).
The present checklist is the fourth checklist on monogeneans of fishes of Iraq, as a continuation to previous checklist concerned with Gyrodactylus species (Mhaisen \& Abdul-Ameer, 2013), diplozoid species (Mhaisen \& Abdul-Ameer, 2014) and Dactylogyrus species (Mhaisen \& AbdulAmeer, 2019). The aims of the present article are to revise Iraqi data on members of the families Ancylodiscoididae and Ancyrocephalidae parasitizing fishes as such monogeneans and their hosts exhibited various synonyms and to provide updated parasite-host list and host-parasite list.

\section{Materials \& Methods}

Fifty-nine references (29 research papers, 20 unpublished M. Sc. theses, five Ph. D. theses and five conference abstracts) dealing with these two families of monogenean parasites of fishes of Iraq were used to prepare the present article. Data from such references were gathered to provide parasite-fish list and fishparasite list based on EOL (2019), GBIF (2019) and WoRMS (2019). For fishes, the scientific names were reported as they appeared in their original references but then they were checked with an account on freshwater fishes of Iraq (Coad, 2010). Fish valid names and their authorities were corrected according to well-known specialized electronic site (Fricke et al., 2019).

\section{Results \& Discussion}

\section{Surveys achieved on ancylodiscoidids and ancyrocephalids from fishes of Iraq}

The present article of available literature concerning the occurrence of ancylodiscoidid and ancyrocephalid monogeneans of fishes of Iraq indicated that the first record of such families was that of Thaparocleidus vistulensis (as Ancylodiscoides vistulensis) by 
Mhaisen \& Abdul-Ameer/ Basrah J. Agric. Sci., 32(Spec. Issue 2): 45-62, 2019

Abdul-Ameer (1989). After that, some surveys were achieved in different waters in Iraq which contributed in recording more species of these two families. The records of these parasites from fishes of Iraq can be grouped into seven major categories according to localities of collection of the infected fishes. For each category, references are chronologically listed. These categories are:

1- Tigris river at Nineveh province (AlNiaeemi, 1997; Rahemo \& Al-Neemi, 1999; Rahemo \& Al-Niaeemi, 2001), Salah Al-Din province (Abdul-Ameer, 1989; Esmaeel, 2018; Owaied et al., 2018) and Baghdad province (Mhaisen et al., 1997; Adday et al., 1999; Mhaisen et al., 2003; Mansor et al., 2012; Al-Saadi, 2013a; Al-Jawda \& Asmar, 2014, 2015; Abdul-Ameer \& Atwan, 2016; Atwan, 2016; Rasheed, 2016; Abdul-Ameer, 2017; Hammood, 2017; Abbas, 2019) as well as some tributaries of Tigris river which included Greater Zab river (Abdullah, 2002; Abdullah \& Mhaisen, 2004; Kritsky et al., 2004; Bashê, 2008; Shwani, 2009; Abdullah \& Shwani, 2010; Bashê \& Abdullah, 2010a, b; Bilal, 2016), Lesser Zab river (Abdullah, 2002; Abdullah \& Mhaisen, 2004) and Diyala river (Abdul-Ameer \& Obaid, 2011; Mohammed, 2017).

2- Euphrates river and its branches at Babylon province (Al-Sa'adi, 2007; Mhaisen et al., 2015) and Al-Muthanna province (Al-Helli, 2019).

3- Shatt Al-Arab river (Kritsky et al., 2013) and its branches at Basrah province which included Garmat Ali river (Jori, 1998; AbdulRahman, 1999; Al-Salim \& Jori, 2000; Adday, 2001; Kadhim, 2009; Khamees et al., 2012) and Al-Salihiya river (Al-Janae'e, 2010).
4- Some lakes and marshes: These included Darbandikhan lake at Sulaymaniyah province (Abdullah, 2013; Abdullah \& Abdullah, 2015a, b), Hemrin dam lake at Diyala province (Balasem et al., 2000) and AlHammar marsh at Basrah province (Jori, 2006; Abbas, 2007; Awad et al. (2007a, b, c).

5- Man-made lake at Baghdad province (AlNasiri, 2000; Al-Nasiri et al., 2003).

6- Fish markets at Baghdad province (AbdulAmeer, 2012; Al-Saadi, 2013b).

7- Marine waters of Khor Al-Zubair lagoon and Khor Abdullah, northwest of the Arab Gulf (Al-Daraji, 1995; Bannai, 2002; Bannai et al., 2005; Jori \& Mohamad, 2008).

Surveying literature concerning the ancylodiscoidid and ancyrocephalid monogeneans of fishes of Iraq showed the infection of 19 valid fish species with 30 parasite taxa. The full authority of each valid fish host species is shown in table (1).

\section{Parasite-host list}

Species of the ancylodiscoidid and ancyrocephalid monogeneans so far parasitic on fishes of Iraq are listed in table (2).

The following is a brief account on the occurrence of these parasites in fishes of Iraq. They are alphabetically listed within their two families (Ancylodiscoididae and Ancyrocephalidae). Names of valid fish host species for each monogenean species are also alphabbetically arranged.

\section{Family Ancylodiscoididae}

The family Ancylodiscoididae is represented in fishes of Iraq with 11 species. These are: one species each of the genera Ancylodiscoides, Bychowskyella, Chauhanellus and Hamatopeduncularia, six species of Thaparocleidus as well as one unidentified species of Hamatopeduncularia. 
Mhaisen \& Abdul-Ameer/ Basrah J. Agric. Sci., 32(Spec. Issue 2): 45-62, 2019

Ancylodiscoides parasiluri Yamaguti, 1937 was recorded only from gills of Silurus triostegus by Jori (2006), who considered it as a member of the subfamily Ancyrocephalinae of the family Dactylogyridae and by Abbas (2007), who also considered it as a member of the same subfamily and family. Awad et al. $(2007 b, c)$ also reported this parasite from the same fish and locality. GBIF (2019) listed two valid species of the genus Ancylodiscoides Yamaguti, 1937, inclusive of $A$. parasiluri. However, both EOL (2019) and WoRMS (2019) listed three valid species of this genus, inclusive of $A$. parasiluri.

Table (1): Valid fish species of Iraq with ancylodiscoidid and ancyrocephalid infections.

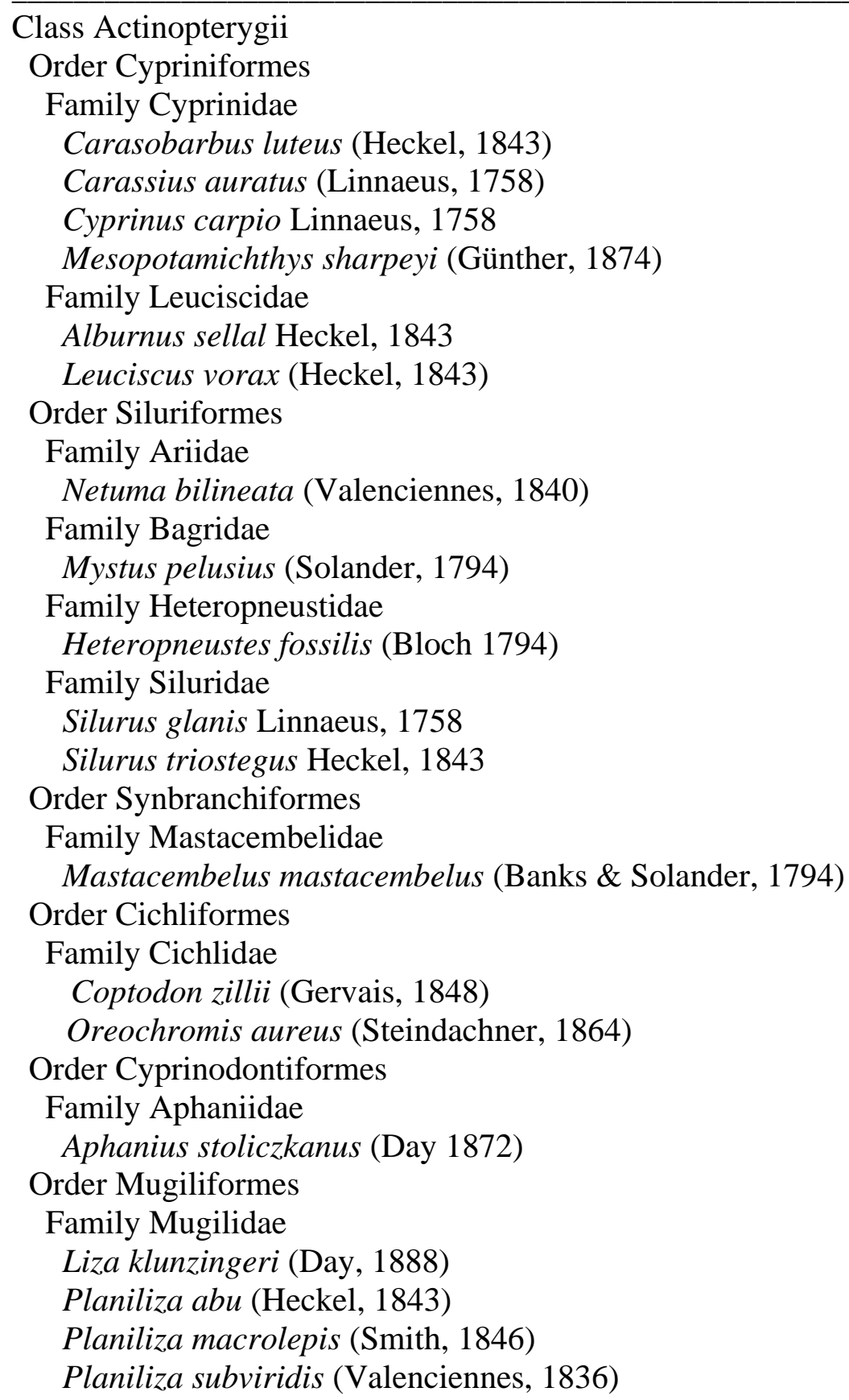




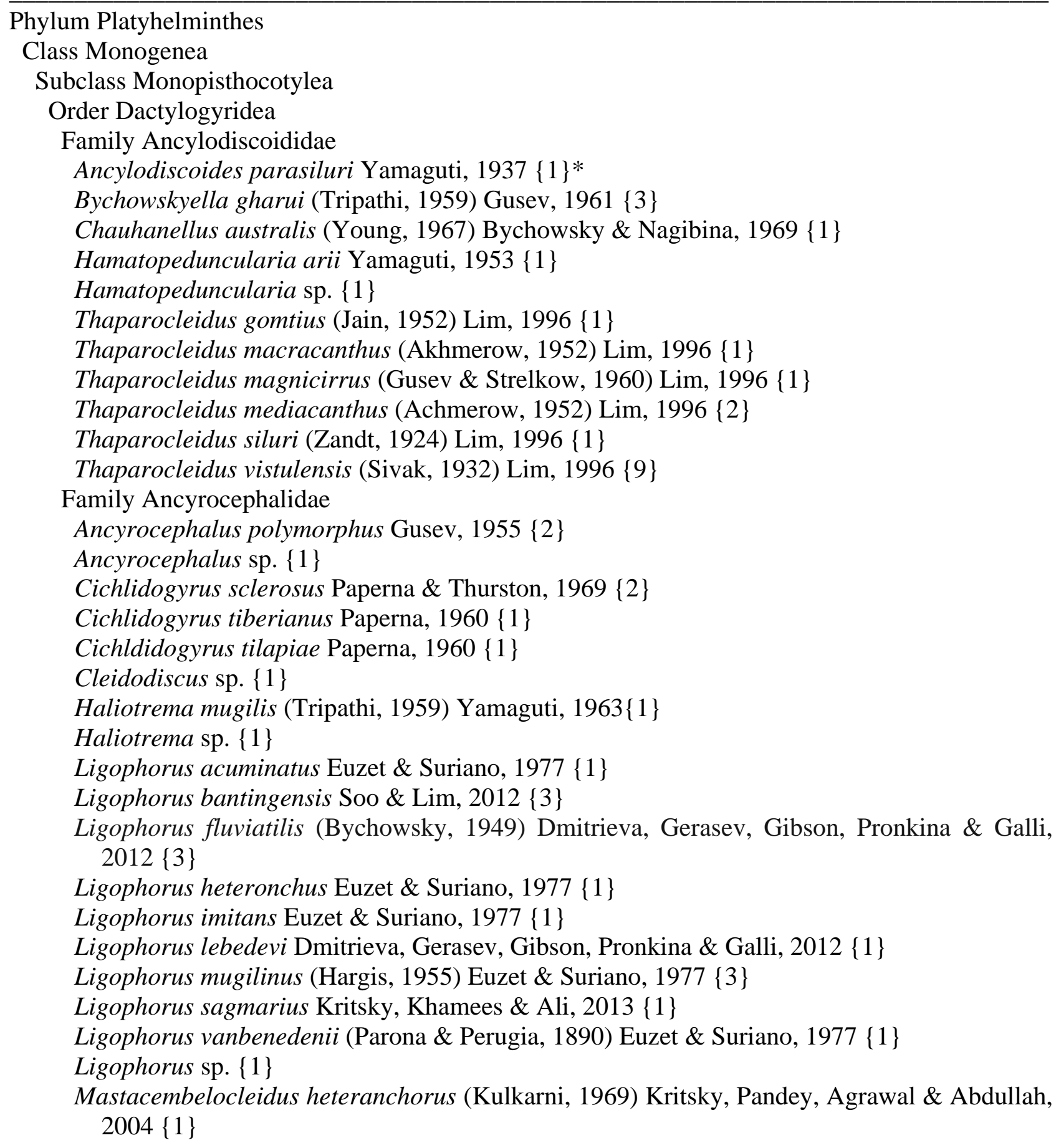

\footnotetext{
* Numbers in curly brackets occurring after the authority of each parasite species refer to number of host species recorded for that parasite from the whole waters of Iraq based on Mhaisen (2019).
}

Bychowskyella gharui (Tripathi, 1959) Gusev, 1961 was recorded from gills of three fish species: Carasobarbus luteus (as Barbus luteus) by Esmaeel (2018), Cyprinus carpio by Esmaeel (2018) and Owaied et al. (2018) as well as S. triostegus by Jori (2006). It is reliable to state here that both Esmaeel (2018) and Owaied et al. (2018) had misspelled the generic name of this parasite as Bychowskylla instead of Bychowskyella, its specific name as qhauri instead of gharui, its authority as Tripathi, 1959 instead of the 


\section{Mhaisen \& Abdul-Ameer/ Basrah J. Agric. Sci., 32(Spec. Issue 2): 45-62, 2019}

above corrected authority and its family as Gyrodactylidae instead of Ancylodiscoididae. On the other hand, Jori (2006) considered this parasite as a member of the subfamily Ancyrocephalinae of the family Dactylogyridae. WoRMS (2019) listed five synonyms of B. gharui: Bychowskyella gussevi Agrawal \& Sharma, 1990 nec Majumdar \& Agarwal, 1989; Silonditrema chauhani Agrawal \& Singh, 1981; Silonditrema gharui Tripathi, 1959; Silonditrema lucknowensis Agrawal \& Singh, 1981 and Silonditrema yogendrai Agrawal \& Singh, 1981. GBIF (2019) also considered these as synonyms, except $B$. gussevi which was considered as a valid species. According to GBIF (2019), the genus Bychowskyella Akhmerov, 1952 includes 29 species. EOL (2019) listed seven valid species of this genus, inclusive of B. gharui, while WoRMS (2019) listed 25 valid species of this genus, inclusive of $B$. gharui. As species of Bychowskyella are parasites of silurid fishes (Lim et al., 2001), so their records from non silurid fishes might be as a result of misidentification.

Chauhanellus australis (Young, 1967) Bychowsky \& Nagibina, 1969 was reported as Hamatopeduncularia australis Young, 1967 from gills of Netuma bilineata (as Arius bilineatus) by Al-Daraji (1995). GBIF (2019) and WoRMS (2019) recognized H. australis as a synonym of $C$. australis. The genus Chauhanellus Bychowsky \& Nagibina, 1969 includes 30 accepted species (GBIF, 2019; WoRMS, 2019) while EOL (2019) listed only seven accepted species. According to a personal communication of the senior author on 15 September 2019 with Dr. David I. Gibson, the classification of Ancylodiscoididae in WoRMS (2019) is following Lim et al. (2001).
Hamatopeduncularia arii Yamaguti, 1953 was recorded only from gills of S. triostegus by Jori (2006) and Awad et al. (2007a). Jori (2006) considered this parasite as a member of the subfamily Ancyrocephalinae of the family Dactylogyridae. EOL (2019), GBIF (2019) and WoRMS (2019) listed H. arii among the valid species of the genus Hamatopeduncularia of the family Ancylodiscoididae.

Hamatopeduncularia sp. was recorded from gills of the marine fish Netuma bilineata (as Arius bilineatus) by Al-Daraji (1995) and Jori \& Mohamad (2008). According to GBIF (2019), the genus Hamatopeduncularia Yamaguti, 1953 includes 34 valid species, while WoRMS (2019) listed 26 valid species and EOL (2019) listed 24 species.

Thaparocleidus gomtius (Jain, 1952) Lim, 1996 was reported as Ancylodiscoides gomtius from gills of S. triostegus by Mhaisen et al. (1997, 2003) and Al-Sa'adi (2007), as Haplocleides gomtius by Adday et al. (1999) and as Thaparocleidus gomtius by Mhaisen et al. (2015). It is reliable to state here that all these five above-named references had erroneously misspelled the specific name of this parasite as gomitus instead of gomtius. According to GBIF (2019) and WoRMS (2019), Haplocleides gomtius Jain, 1952; Paradiscocoides gomtius (Jain, 1952) Dubey, Gupta \& Agarwal, 1992 and Silurodiscoides gomtius (Jain, 1952) Gusev, 1976 are all synonyms of $T$. gomtius. EOL (2019), GBIF (2019) and WoRMS (2019) listed 128, 121 and seven species, respectively of Thaparocleidus Jain, 1952 inclusive of $T$. gomtius.

Thaparocleidus macracanthus (Akhmerow, 1952) Lim, 1996 was recorded from gills of $S$. triostegus by Mohammed (2017). This is, so far, the only record of this 
Mhaisen \& Abdul-Ameer/ Basrah J. Agric. Sci., 32(Spec. Issue 2): 45-62, 2019

parasite from fishes of Iraq. T. macracanthus is considered as a valid species within the genus Thaparocleidus Jain, 1952 according to EOL (2019), GBIF (2019) and WoRMS (2019).

Thaparocleidus magnicirrus (Gusev \& Strelkow, 1960) Lim, 1996 was recorded from gills of $S$. triostegus by Mohammed (2017). This is so far, the only record of this parasite from fishes of Iraq. T. magnicirrus is considered as a valid species within the genus Thaparocleidus according to EOL (2019), GBIF (2019) and WoRMS (2019).

Thaparocleidus mediacanthus (Achmerow, 1952) Lim, 1996 was recorded from gills of Carasobarbus luteus (as Barbus luteus) by Abdul-Ameer \& Obaid (2011) as Silurodiscoides mediacanthus and from gills of S. triostegus and as T. mediacanthus by Mohammed (2017). GBIF (2019) and WoRMS (2019) recognized Ancylodiscoides mediacanthus Achmerow, 1952; Parancylodiscoides mediacanthus (Achmerow, 1952) Achmerow, 1964 and Silurodiscoides mediacanthus (Achmerow, 1952) Gusev, 1985 as synonyms of T. mediacanthus. EOL (2019) also listed T. mediacanthus as a valid species.

Thaparocleidus siluri (Zandt, 1924) Lim, 1996 was recorded from gills of S. triostegus as Ancyrocephalus siluri by Balasem et al. (2000) and by Al-Jawda \& Asmar (2014) as T. siluri. Mansor et al. (2012) also reported this parasite, as A. siluri, without naming its host. According to a personal communication with J. M. Al-Jawda, this host is likely to be S. triostegus as N. T. Mansor (who is working with Al-Jawda) took the related data from him. GBIF (2019) and WoRMS (2019) recognized Ancylodiscoides siluri (Zandt, 1924) Yamaguti, 1963; Ancyrocephalus siluri Zandt, 1924; Parancylodiscoides siluri
(Zandt, 1924) Achmerow, 1964; Silurodiscoides siluri (Zandt, 1924) Gusev, 1976 and Urocleidus siluri (Zandt, 1924) Mizelle \& Hughes, 1938 as synonyms of $T$. siluri. EOL (2019) also listed T. siluri as a valid species.

Thaparocleidus vistulensis (Sivak, 1932) Lim, 1996 was reported from gills of Alburnus sellal (as Chalcalburnus sellal), Heteropneustes fossilis, Leuciscus vorax (as Aspius vorax), Mastacembelus mastacembelus and Mesopotamichthys sharpeyi (as Barbus sharpeyi) by Abdul-Rahman (1999) as well as from Mystus pelusius by both Abdul-Rahman (1999) and Adday (2001), Planiliza abu (as Liza abu) by Abdul-Rahman (1999), Silurus glanis by Al-Niaeemi (1997), Rahemo \& Al-Neemi (1999), Rahemo \& AlNiaeemi (2001), Abdullah (2002) and Abdullah \& Mhaisen (2004) and S. triostegus by Abdul-Ameer (1989), Abdul-Rahman (1999), Adday (2001), Al-Sa'adi (2007), Shwani (2009), Abdullah \& Shwani (2010), Abdullah (2013), Abdullah \& Abdullah (2015a, b), Al-Jawda \& Asmar (2015), Mhaisen et al. (2015), Bilal (2016) and AlHelli (2019). It is reliable to state here that all the above named references, concerning this monogenean, referred to it with its synonymous name Ancylodiscoides vistulensis, except Abdullah (2013), Abdullah \& Abdullah (2015a, b), Al-Jawda \& Asmar (2015), Mhaisen et al. (2015), Bilal (2016) and Al-Helli (2019) who referred to it with its valid name $T$. vistulensis. GBIF (2019) and WoRMS (2019) recognized four synonyms for T. vistulensis which are: Ancylodiscoides vistulensis (Sivak, 1932) Yamaguti, 1963; Ancyrocephalus vistulensis Sivak, 1932; Silurodiscoides vistulensis (Sivak, 1932) Gusev, 1985 and Urocleidus vistulensis (Sivak, 1932) Mizelle \& Hughes, 1938. EOL (2019) also listed T. vistulensis as a valid 
Mhaisen \& Abdul-Ameer/ Basrah J. Agric. Sci., 32(Spec. Issue 2): 45-62, 2019

species. In connection with the presence of this parasite on nine fish host species in Iraq, inclusive of non siluriform fishes, it is possible that misidentification might occur as this parasite is known to infect only silurid fishes (Lim et al., 2001; Pugachev et al., 2009; EOL, 2019).

\section{Family Ancyrocephalidae}

The family Ancyrocephalidae is represented in fishes of Iraq with 19 species. These are: one species each of the genera Ancyrocephalus, Haliotrema and Mastacembelocleidus, three species of Cichlidogyrus, nine species of Ligophorus as well as unidentified species of the genera Ancyrocephalus, Cleidodiscus, Haliotrema and Ligophorus.

Ancyrocephalus polymorphus Gusev, 1955 was reported from gills of both Aphanius stoliczkanus (misidentified as Aphanius dispar) by Kadhim (2009) and Khamees et al. (2012) and Carassius auratus by Al-Janae'e (2010). A. polymorphus is considered as a valid species by EOL (2019), GBIF (2019) and WoRMS (2019). According to WoRMS (2019), the subspecies Ancyrocephalus polymorphus typica Gusev, 1955 is considered as a synonym of $A$. polymorphus.

Ancyrocephalus species was recorded from gills of Planiliza subviridis (as Liza subviridis) by Al-Daraji (1995). WoRMS (2019) listed 39 valid species of the genus Ancyrocephalus Creplin, 1839, while GBIF (2019) listed 45 accepted species of this genus.

Cichlidogyrus sclerosus Paperna \& Thurston, 1969 was reported from gills of Coptodon zillii by Abdul-Ameer \& Atwan (2016), Atwan (2016), Rasheed (2016), Abbas (2019) and Al-Helli (2019) as well as from gills of Oreochromis aureus by AbdulAmeer \& Atwan (2016), Atwan (2016),
Abbas (2019) and Al-Helli (2019). According to GBIF (2019) and WoRMS (2019), C. sclerosus has one synonym which is Cichlidogyrus bangladeshi Ferdousi \& Chandra, 2002.

Cichlidogyrus tiberianus Paperna, 1960 was reported from gills of Coptodon zillii by Atwan (2016), Rasheed (2016), Abdul-Ameer (2017) and Mohammed (2017). C. tiberianus is considered as a valid species according to EOL (2019), GBIF (2019) and WoRMS (2019).

Cichldidogyrus tilapiae Paperna, 1960 was reported from gills of Coptodon zillii by Abdul-Ameer \& Atwan (2016) and Atwan (2016). According to GBIF (2019) and WoRMS (2019), C. tilapiae has two synonyms: Cleidodiscus tilapiae (Paperna, 1960) Price, 1967 and Cichlidogyrus chandrai Ferdousi \& Chandra, 2002. GBIF (2019) listed 126 species of the genus Cichlidogyrus Paperna, 1960, while WoRMS (2019) listed 123 species, and in both sites, $C$. tilapiae is considered as a valid species.

Cleidodiscus species was reported from gills of S. triostegus by Jori (2006) who considered this species within the subfamily Ancyrocephalinae of the family Dactylogyridae. GBIF (2019) listed 15 species of the genus Cleidodiscus Mueller, 1934, while EOL (2019) listed six species and WoRMS (2019) listed seven accepted species for this genus. It is appropriate to mention here that the genus Cleidodiscus is considered within the family Ancylodiscoididae only by MonoDb (2019). The first author of this article received no any answer from eight concerned scientists (see the acknowledgement section of this article for their names) in MonoDb (2019) about this consideration. 
Mhaisen \& Abdul-Ameer/ Basrah J. Agric. Sci., 32(Spec. Issue 2): 45-62, 2019

Haliotrema mugilis (Tripathi, 1959) Yamaguti, 1963 was reported from gills of Planiliza subviridis (as Liza subviridis) by AlDaraji (1995) and Bannai (2002) who both considered this parasite within the subfamily Ancyrocephalinae and the family Dactylogyridae. This is a valid species according to EOL (2019), GBIF (2019) and WoRMS (2019). The two latter electronic sites recognized Ancylodiscoides mugilis Tripathi, 1959 as a synonym of $H$. mugilis.

Haliotrema species was reported from gills of S. triostegus by Jori (2006) who considered this species within the subfamily Ancyrocephalinae of the family Dactylogyridae. According to Lim et al. (2001), members of the genus Haliotrema infect nonsiluriform hosts. GBIF (2019) listed 145 species of the genus Haliotrema Johnston \& Tiegs, 1922, while WoRMS (2019) listed 141 valid species of this genus.

Ligophorus acuminatus Euzet \& Suriano, 1977 was reported only from gills of Planiliza $a b u$ (as Liza abu) by Abdul-Ameer (2012). $L$. acuminatus is considered as a valid species according to EOL (2019), GBIF (2019) and WoRMS (2019).

Ligophorus bantingensis Soo \& Lim, 2012 was reported by Kritsky et al. (2013) from gills of three mullet species: Liza klunzingeri, Planiliza abu (as Liza abu) and Planiliza subviridis (as Chelon subviridis). This is a valid species according to GBIF (2019) and WoRMS (2019).

Ligophorus fluviatilis (Bychowsky, 1949) Dmitrieva, Gerasev, Gibson, Pronkina \& Galli, 2012 was reported from gills of three fish species: Liza klunzingeri by Kritsky et al. (2013), Planiliza abu (also as Liza $a b u$ ) by Kritsky et al. (2013), Atwan (2016) and Hammood (2017) and Planiliza subviridis (as Chelon subviridis) by Kritsky et al. (2013).
This is a valid species according to EOL (2019), GBIF (2019) and WoRMS (2019). The two latter electronic sites recognized Ancyrocephalus fluviatilis as a synonym of $L$. fluviatilis.

Ligophorus heteronchus Euzet \& Suriano, 1977 was recorded from gills of only Planiliza abu (as Liza abu) by Al-Saadi (2013b). L. heteronchus is a valid species according to EOL (2019), GBIF (2019) and WoRMS (2019).

Ligophorus imitans Euzet \& Suriano, 1977 was recorded from gills of only Planiliza $a b u$ (as Liza $a b u$ ) by Al-Saadi (2013a). This parasite is a valid species according to EOL (2019), GBIF (2019) and WoRMS (2019).

Ligophorus lebedevi Dmitrieva, Gerasev, Gibson, Pronkina \& Galli, 2012 was recorded from gills of only Planiliza subviridis (as Chelon subviridis) by Kritsky et al. (2013). L. lebedvi is a valid species according to EOL (2019), GBIF (2019) and WoRMS (2019).

Ligophorus mugilinus (Hargis, 1955) Euzet \& Suriano, 1977 was reported as Haliotrema mugilinus Hargis, 1955 from gills of three mullet species: Planiliza abu (as $L$. $a b u$ ) by Jori (1998) and Al-Salim \& Jori (2000), Planiliza macrolepis (as Liza macrolepis) by Al-Daraji (1995) and Planiliza subviridis (as Liza subviridis) by AlDaraji (1995), Jori (1998), Al-Salim \& Jori (2000) and Bannai et al. (2005). According to GBIF (2019) and WoRMS (2019), both Haliotrema mugilinus (Hargis, 1955) and Pseudohaliotrema mugilinus Hargis, 1955 are considered as synonyms of L. mugilinus.

Ligophorus sagmarius Kritsky, Khamees \& Ali, 2013 was reported from gills of Planiliza subviridis (as Chelon subviridis) by Kritsky et al. (2013). L. sagmarius is a valid species according to EOL (2019), GBIF (2019) and WoRMS (2019). 
Mhaisen \& Abdul-Ameer/ Basrah J. Agric. Sci., 32(Spec. Issue 2): 45-62, 2019

Ligophorus vanbenedenii (Parona \& Perugia, 1890) Euzet \& Suriano, 1977 was reported from gills of Planiliza abu (as Liza $a b u)$ by Mhaisen et al. (1997), Adday et al. (1999), Al-Nasiri (2000) Al-Nasiri et al. (2003), Mhaisen et al. (2003), Al-Sa'adi (2007), Al-Jawda \& Asmar (2014) and Mhaisen et al. (2015). All these references, except Al-Jawda \& Asmar (2014) and Mhaisen et al. (2015) had reported this parasite as Ancyrocephalus vanbenedenii. According to GBIF (2019) and WoRMS (2019), L. vanbenedenii has six synonyms: Ancyrocephalus vanbenedenii (Parona \& Perugia, 1890) Johnston \& Tiegs, 1922; Dactylogyrus benedeni Saint-Remy, 1898; Dactylogyrus vanbenedenii Parona \& Perugia, 1895, Haliotrema vanbenedeni (Parona \& Perugia, 1890) Young, 1968; Haplolcleidus vanbenedenii (Parona \& Perugia, 1890) Palombi, 1949 and Tetraonchus vanbenedenii Parona \& Perugia, 1890. EOL (2019) also considered $L$. vanbenedenii as a valid species.

Ligophorus species was reported from gills of Liza klunzingeri by Kritsky et al. (2013). GBIF (2019) listed 68 accepted species within the genus Ligophorus Euzet \& Soriano, 1977 while WoRMS (2019) listed 60 accepted species within this genus.

Mastacembelocleidus heteranchorus (Kulkarni, 1969) Kritsky, Pandey, Agrawal \& Abdullah, 2004 was reported from gills of Mastacembelus mastacembelus by Kritsky et al. (2004), Al-Sa'adi (2007), Bashê (2008), Bashê \& Abdullah (2010a, b), Abdullah (2013), Abdullah \& Abdullah (2015a, b), Mhaisen et al. (2015), Atwan (2016), Mohammed (2017) and Al-Helli (2019). This parasite was described as species de novo by Kritsky et al. (2004) who considered it within the family Dactylogyridae. According to GBIF (2019) and WoRMS (2019), $M$. heteranchorus has one synonym which is
Urocleidus heteranchorus Kulkarni, 1969. The genus Mastacembelocleidus Kritsky, Pandey, Agrawal \& Abdullah, 2004 has two valid species, inclusive of $M$. heteranchorus according to EOL (2019), GBIF (2019) and WoRMS (2019).

The previous parasite-host list of the present article identified eight synonyms for seven species of both ancylodiscoidids and ancyrocephalids infecting fishes of Iraq. These are:

1- Ancylodiscoides gomtius as a synonym of Thaparocleidus gomtius.

2- Haplocleides gomtius as a synonym of Thaparocleidus gomtius.

3- Silurodiscoides mediacanthus as a synonym of Thaparocleidus mediacanthus.

4- Ancylodiscoides siluri as a synonym of Thaparocleidus siluri.

5- Ancylodiscoides vistulensis as a synonym of Thaparocleidus vistulensis.

6- Hamatopeduncularia australis as a synonym of Chauhanellus australis.

7- Haliotrema mugilinus as a synonym of Ligophorus mugilinus.

8- Ancyrocephalus vanbenedenii as a synonym of Ligophorus vanbenedenii.

The list of valid ancylodiscoidid and ancyrocephalid monogeneans infecting valid fish species of Iraq is demonstrated in table (3).

\section{Host-parasite list}

Names of all fish host species of Iraq, infected with ancylodiscoidid and ancyrocephalid mmonogeneans (19 valid fish names and ten synonyms) are alphabetically arranged in the following list. For each valid host species, parasite species are alphabetically arranged 
Mhaisen \& Abdul-Ameer/ Basrah J. Agric. Sci., 32(Spec. Issue 2): 45-62, 2019

according to the sequence of their families. For fishes, the scientific names were reported as they appeared in their original references but they were then checked with an account on freshwater fishes of Iraq (Coad, 2010). As indicated earlier in the section of Sources and Methods, fish valid scientific names were checked according to Fricke et al. (2019).

Table (3): Species of Ancylodiscoididae and Ancyrocephalidae with their fish host species.

\begin{tabular}{|c|c|}
\hline \multicolumn{2}{|r|}{ Family Ancylodiscoididae } \\
\hline Ancylodiscoides parasiluri & Silurus triostegus \\
\hline Bychowskyella gharui & Carasobarbus luteus, Cyprinus carpio, Silurus triostegus \\
\hline Chauhanellus australis & Netuma bilineata \\
\hline Hamatopeduncularia arii & Silurus triostegus \\
\hline Hamatopeduncularia sp. & Netuma bilineata \\
\hline Thaparocleidus gomtius & Silurus triostegus \\
\hline Thaparocleidus macracanthus & Silurus triostegus \\
\hline Thaparocleidus magnicirrus & Silurus triostegus \\
\hline Thaparocleidus mediacanthus & Carasobarbus luteus, Silurus triostegus \\
\hline Thaparocleidus siluri & Silurus triostegus \\
\hline Thaparocleidus vistulensis & $\begin{array}{l}\text { Alburnus sellal, Heteropneustes fossilis, Leuciscus vorax, } \\
\text { Mastacembelus mastacembelus, Mesopotamichthys sharpeyi, } \\
\text { Mystus pelusius, Planiliza abu, Silurus glanis, S. triostegus }\end{array}$ \\
\hline \multicolumn{2}{|r|}{ Family Ancyrocephalidae } \\
\hline Ancyrocephalus polymorphus & Aphanius stoliczkanus, Carassius auratus \\
\hline Ancyrocephalus sp. & Planiliza subviridis \\
\hline Cichlidogyrus sclerosus & Coptodon zillii, Oreochromis aureus \\
\hline Cichlidogyrus tiberianus & Coptodon zillii \\
\hline Cichldidogyrus tilapiae & Coptodon zillii \\
\hline Cleidodiscus sp. & Silurus triostegus \\
\hline Haliotrema mugilis & Planiliza subviridis \\
\hline Haliotrema sp. & Silurus triostegus \\
\hline Ligophorus acuminatus & Planiliza abu \\
\hline Ligophorus bantingensis & Liza klunzingeri, Planiliza abu, $P$. subviridis \\
\hline Ligophorus fluviatilis & Liza klunzingeri, Planiliza abu, $P$. subviridis \\
\hline Ligophorus heteronchus & Planiliza abu \\
\hline Ligophorus imitans & Planiliza $a b u$ \\
\hline Ligophorus lebedevi & Planiliza subviridis \\
\hline Ligophorus mugilinus & Planiliza abu, P. macrolepis, $P$. subviridis \\
\hline Ligophorus sagmarius & Planiliza subviridis \\
\hline Ligophorus vanbenedenii & Planiliza abu \\
\hline Ligophorus sp. & Liza klunzingeri \\
\hline $\begin{array}{l}\text { Mastacembelocleidus } \\
\text { heteranchorus }\end{array}$ & Mastacembelus mastacembelus \\
\hline
\end{tabular}


Mhaisen \& Abdul-Ameer/ Basrah J. Agric. Sci., 32(Spec. Issue 2): 45-62, 2019

Alburnus sellal (reported as Chalcalburnus sellal)

Family Ancylodiscoididae: Thaparocleidusus vistulensis (as Ancylodiscoides vistulensis).

Aphanius dispar: See Aphanius stoliczkanus.

Aphanius stoliczkanus

Family Ancyrocephalidae: Ancyrocephalusus polymorphus.

Arius bilineatus: See Netuma bilineata.

Aspius vorax: See Leuciscus vorax.

Barbus luteus: See Carasobarbus luteus.

Barbus sharpeyi: See Mesopotamichthys sharpeyi.

Carasobarbus luteus (reported as Barbus luteus)

Family Ancylodiscoididae: Bychowskyella gharui, Thaparocleidus mediacanthus (as Silurodiscoides mediacanthus).

\section{Carassius auratus}

Family Ancyrocephalidae: Ancyrocephalusus polymorphus.

Chalcalburnus sellal: See Alburnus sellal.

Coptodon zillii

Family Ancyrocephalidae: Cichlidogyrus sclerosus, C. tiberianus, C. tilapiae.

Cyprinus carpio

Family Ancylodiscoididae: Bychowskyella gharui.

Chelon subviridis: See Planiliza subviridis.

Heteropneustes fossilis

Family Ancylodiscoididae: Thaparocleidus vistulensis (as Ancylodiscoides vistulensis).

Leuciscus vorax (reported as Aspius vorax)

Family Ancylodiscoididae: Thaparocleidus vistulensis (as Ancylodiscoides vistulensis).

Liza abu: See Planiliza abu.

Liza klunzingeri

Family Ancyrocephalidae: Ligophorus bantingensis, L. fluviatilis, Ligophorus sp.
Liza macrolepis: See Planiliza macrolepis.

Liza subviridis: See Planiliza subviridis.

Mastacembelus mastacembelus

Family Ancylodiscoididae: Thaparocleidus vistulensis (as Ancylodiscoides vistulensis).

Family Ancyrocephalidae: Mastacembelocleidus heteranchorus.

Mesopotamichthys sharpeyi (reported as Barbus sharpeyi)

Family Ancylodiscoididae: Thaparocleidus vistulensis (as Ancylodiscoides vistulensis).

Mystus pelusius

Family Ancylodiscoididae: Thaparocleidus vistulensis (as Ancylodiscoides vistulensis).

Netuma bilineata (reported as Arius bilineatus)

Family Ancylodiscoididae: Chauhanellus australis (as Hamatopeduncularia australis), Hamatopeduncularia sp.

Oreochromis aureus

Family Ancyrocephalidae: Cichlidogyrus sclerosus.

Planiliza abu (also reported as Liza abu)

Family Ancylodiscoididae: Thaparocleidus vistulensis (as Ancylodiscoides vistulensis).

Family Ancyrocephalidae: Ligophorus acuminatus, L. bantingensis, L. fluviatilis, L. heteronchus, L. imitans, L. mugilinus (as Haliotrema mugilinus), L. vanbenedenii (also as Ancyrocephalus vanbenedenii).

Planiliza macrolepis (as Liza macrolepis)

Family Ancyrocephalidae: Ligophorus mugilinus (as Haliotrema mugilinus).

Planiliza subviridis (reported also as Chelon subviridis and Liza subviridis)

Family Ancyrocephalidae: Ancyrocephalus sp., Haliotrema mugilis, Ligophorus bantingensis, L. fluviatilis, L. lebedevi, L. mugilinus (as Haliotrema mugilinus), L. sagmarius.

Silurus glanis

Family Ancylodiscoididae: Thaparocleidus vistulensis (as Ancylodiscoides vistulensis).

Silurus triostegus 
Mhaisen \& Abdul-Ameer/ Basrah J. Agric. Sci., 32(Spec. Issue 2): 45-62, 2019

Family Ancylodiscoididae: Ancylodiscoides parasiluri, Bychowskyella gharui, Hamatopeduncularia arii, Thaparocleidus gomtius (also as Ancylodiscoides gomtius and as Haplocleides gomtius), $T$. macracanthus, $T$. magnicirrus, $T$. mediacanthus, T. siluri (also as Ancylodiscoides siluri), T. vistulensis (also as Ancylodiscoides vistulensis).

Family Ancyrocephalidae: Cleidodiscus sp., Haliotrema sp.

\section{Acknowledgements}

The first author of this article expresses his sincere thanks to Dr. David I. Gibson of the British Museum (Natural History) for his comments on some monogenean species. Thanks also are due to Mr. Jawdat M. AlJawda of Animal and Fish Research Center, Agriculture Research Directorate, Ministry of Science and Technology, Baghdad, Iraq for his comments concerning some records appeared in a paper by Mansor et al. (2012). On the other hand, the first author condemn

the negative abstention response of some of the concerned staff of the MonoDb (Prof. Tor Bakke, Dr. James Bron, Dr. Joanne Cable, Dr. Kevin Christison, Prof. Phil Harris, Dr. Andrew Shinn, Prof. Dr. Ian Whittington and Dr. Gil Ha Yoon) toward 14 e-mail letters forwarded to them about the allocation of some monogeneans in MonoDb (2019) in contrast to their allocation in EOL (2019), GBIF (2019) and WoRMS (2019).

\section{Conflicts of interest}

The authors declare that they have no conflict of interests.

Ethical approval: All applicable national and international guidelines for the care and use of animals were followed.

\section{References}

Abbas, A.A.-K. (2007). Histopathological studies of some parasites of the Asian catfish, Silurus triostegus (Heckel, 1843) and potassium permanganate on the black molly, Poecilia sphenops (Valenciennes, 1846). Ph. D. Thesis, Coll. Educ., Univ. Basrah: 144pp. (In Arabic).

Abbas, J.A. (2019). The parasitic fauna of some species of fishes from Tigris river at Al-Autaifia region, Baghdad province, Iraq. M. Sc. Thesis, Coll. Educ. Pure Sci. Ibn Al-Haitham, Univ. Baghdad: 140pp. (In Arabic).

Abdul-Ameer, K.N. (1989). Study of the parasites of freshwater fishes from Tigris river in Salah Al-Dien province, Iraq. M. Sc. Thesis, Coll. Sci., Univ. Baghdad: 98pp. (In Arabic).

Abdul-Ameer, K.N. (2012). Recording of Ligophorus acuminatus Euzet et Suriano, 1977 (Monogenea: Ancyrocephalidae), for the first time in Iraq on gills of freshwater mugilid fish Liza abu (Heckel). Basrah J. Agric. Sci., 25 (Spec. Issue 2): 9-13.

Abdul-Ameer, K.N. (2017). New record of Cichlidogyrus tiberianus Paperna, 1960 (Monogenea, Ancyrocephalidae) from gills of redbelly tilapia Coptodon zillii (Gervais, 1848) in Iraq. Biol. Appl. Environ. Res., 1(1): 88-94.

Abdul-Ameer, K.N. \& Atwan, F.K. (2016). First record of two species of the genus Cichlidogyrus Paperna, 1960 (Monogenea, Ancyrocephalidae) in Iraq on gills of two cichlid fishes. Am. J. Biol. Life Sci., 4(3): 12-15.

Abdul-Ameer, K.N. \& Obaid, A.S. (2011). Recording of the monogenetic trematode Silurodiscoides mediacanthus (Achmerow, 1952) for the first time in Iraq on the gills 
Mhaisen \& Abdul-Ameer/ Basrah J. Agric. Sci., 32(Spec. Issue 2): 45-62, 2019

of the cyprinid fish Barbus luteus. Bull. Iraq Nat. Hist. Mus., 11(3): 1-5.

Abdullah, S.M.A. (2002). Ecology, taxonomy and biology of some parasites of fishes from Lesser Zab and Greater Zab rivers in north of Iraq. Ph. D. Thesis, Coll. Educ. (Ibn Al-Haitham), Univ. Baghdad: 153pp. (In Arabic).

Abdullah, S.M.A. \& Mhaisen, F.T. (2004). Parasitic infections with monogenetic trematodes on fishes of Lesser Zab and Greater Zab rivers in northern Iraq. Zanco, 16(4): 43-52.

Abdullah, S.M.A. \& Shwani, A.A.A. (2010). Ectoparasites of the Asian catfish Silurus triostegus (Heckel, 1843) from Greater Zab river- Kurdistan region- Iraq. J. Duhok Univ., 13(1): 164-171.

Abdullah, Y.S. (2013). Study on the parasites of some fishes from Darbandikhan lake in Kurdistan region, Iraq. M. Sc. Thesis, Fac. Sci. \& Sci. Educ., Univ. Sulaimani: 116pp.

Abdullah, Y.S. \& Abdullah, S.M.A. (2015a). Observations on fishes and their parasites of Darbandikhan lake, Kurdistan region in north Iraq. Am. J. Biol. Life Sci., 3(5): 176-180.

Abdullah, Y.S. \& Abdullah, S.M.A. (2015b). The parasitic infections of some freshwater fishes from Darbandikhan lake, Kurdistan region, Iraq. J. Garmian Univ., 2: 874-884.

Abdul-Rahman, N.M. (1999). Parasites infection in fish from Garmat Ali river and its relation with food items. M. Sc. Thesis, Coll. Agric., Univ. Basrah: 103pp. (In Arabic).

Adday, T.K. (2001). Biology of the crustacean Ergasilus ogawai Kabata, 1992 which parasitized on some Iraqi fishes. M.
Sc. Thesis, Coll. Agric., Univ. Basrah: 117pp. (In Arabic).

Adday, T.K.; Balasem, A.N.; Mhaisen, F.T. \& Al-Khateeb, G.H. (1999). A second survey of fish parasites from Tigris river at Al-Zaafaraniya, south of Baghdad. Ibn Al-Haitham J. Pure Appl. Sci., 12(1): 2231.

Al-Daraji, S.A.M. (1995). Taxonomical and ecological studies on the metazoan parasites of some marine fishes of Khor Al-Zubair estuary, north-west of the Arabian Gulf. Ph. D. Thesis, Coll. Agric., Univ. Basrah: 182pp.

Al-Helli, A.M.S. (2019). Fish assemblage structure and some of its environmental and health aspects in Euphrates river near Samawa city. Ph. D. Thesis, Coll. Agric., Univ. Basrah: 208pp. (In Arabic).

Al-Janae'e, A.M.S. (2010). Parasites of some Iraqi fishes in two localities varied in their trophic levels in inland water of Basrah. M. Sc. Thesis, Coll. Agric., Univ. Basrah: 228pp. (In Arabic).

Al-Jawda, J.M. \& Asmar, K.R. (2014). Monogeneans and trematodes of some fishes from Tigris river at north, mid and south of Baghdad province, Iraq. Iraqi J. Agric. Res. (Special Issue), 19(1): 193202.

Al-Jawda, J.M. \& Asmar, K.R. (2015). A second collection of monogeneans and trematodes (Phylum Platyhelminthes) parasitic on some fishes from Tigris river at Baghdad province, Iraq. Ann. Res. Rev. Biol., 7(2): 126-132.

Al-Nasiri, F.S. (2000). Parasitic infections of fishes in a man-made lake at Al-Amiriya region, Baghdad. M. Sc. Thesis, Coll. Educ. (Ibn Al-Haitham), Univ. Baghdad: 133pp. (In Arabic). 
Mhaisen \& Abdul-Ameer/ Basrah J. Agric. Sci., 32(Spec. Issue 2): 45-62, 2019

Al-Nasiri, F.S. \& Balbuena, J.A. (2017). Ancyrocephalinae (Monogenea: Dactylogyridae) of fishes in Iraq: Literature review and future research. $8^{\text {th }}$ Int. Symp. Monogenea. Brno, Czech Republic: 6-11 August 2017: P. 31. (Abstract).

Al-Nasiri, F.S.; Mhaisen, F.T. \& Al-Nasiri, S.K. (2003). Parasites of the grey mullet Liza $a b u$ in a man-made lake at Baghdad region. Iraqi J. Agric. (Spec. Issue), 8(1): 133-140.

Al-Niaeemi, B.H.S. (1997). A study on parasites of the fish Silurus glanis L., from Tigris river in Mosul city with special reference to the histopathological effects caused by some infections. M. Sc. Thesis, Coll. Sci., Univ. Mosul: 116pp. (In Arabic).

Al-Saadi, A.A.J.J. (2013a). Some parasites from gills of five fish species and the first record of the monogenean Ligophorus imitans Euzet et Suriano, 1977 in Iraq. Ibn Al-Haitham J. Pure Appl. Sci., 26(1): 5663.

Al-Saadi, A.A.J.J. (2013b). Some monogeneans from gills of three freshwater fish species and the first record of Ligophorus heteronchus Euzet \& Suriano, 1977 in Iraq from gills of Liza abu (Heckel, 1843). Basrah J. Agric. Sci., 26(Spec. Issue 1): 99-105.

Al-Sa'adi, B.A.-H.E. (2007). The parasitic fauna of fishes of Euphrates river: Applied study in Al-Musaib city. M. Tech. Thesis, Al-Musaib Technic. Coll., Found. Technic. Educ.: 102pp. (In Arabic).

Al-Salim, N.K. \& Jori, M.M. (2000). Study of the parasites of two mugilid fish and the effect of some on the blood parameters (1Monogenea). Mar. Mesopot., 15(2): 505514. (In Arabic).
Atwan, F.K. (2016). Parasitic infections in some fishes from Tigris river, Al-Graiat location in Baghdad province, Iraq. M. Sc. Thesis, Coll. Educ. Pure Sci. (Ibn AlHaitham), Univ. Baghdad: 136pp. (In Arabic).

Awad, A.H.; Abdullah, F.A. \& Jori, M.M. (2007a). Taxonomic study of parasites of the Asian catfish Silurus triostegus (Heckel, 1843) from Al-Hammar marsh, Basrah, Iraq. $2^{\text {nd }}$ Sci. Conf. Rehabilit. South. Iraqi marshes. Basrah: 2-4 April 2007: 32. (Abst.). (In Arabic).

Awad, A.H.; Abdullah, F.A. \& Jori, M.M. (2007b). Immunological study on the Asian catfish Silurus triostegus (Heckel, 1843) from Al-Hammar marsh, Basrah, Iraq. ${ }^{\text {nd }}$ Sci. Conf. Rehabilit. South. Iraqi marshes. Basrah: 2-4 April 2007: 63. (Abst.). (In Arabic).

Awad, A.H.; Abdullah, F.A. \& Jori, M.M. (2007c). Effect of two parasites on blood parameters of the Asian catfish Silurus triostegus (Heckel, 1843). $2^{\text {nd }}$ Sci. Conf. Rehabilit. South. Iraqi marshes. Basrah: 24 April 2007: 67. (Abst.). (In Arabic).

Balasem, A.N.; Mohammad-Ali, N.R.; Adday, T.K.; Ali, A.K. \& Waheed, I.K. (2000). Parasitological survey on fish in Hemrin dam lake, province of Diyala. J. Diyala, 1(8 part 1): 104-114. (In Arabic).

Bannai, M.A.-A. (2002). Parasites of some marine fishes of Khor Abdulla, north-west Arabian Gulf. M. Sc. Thesis, Coll. Educ., Univ. Basrah: 103pp. (In Arabic).

Bannai, M.A.A.; Al-Daraji, S.A.M.; Jarallah, H.M.; Bannai, A.A. \& Wanes, A.K. (2005). Helminth parasites of grey mullet Liza subviridis (Val., 1836) from Khor Abdullah, Arabian Gulf. Mar. Mesopot., 20(2): 311-316. 
Mhaisen \& Abdul-Ameer/ Basrah J. Agric. Sci., 32(Spec. Issue 2): 45-62, 2019

Bashê, S.K.R. (2008). The parasitic fauna of spiny eel Mastacembelus mastacembelus (Banks and Solander, 1794) from Greater Zab river- Kurdistan region- Iraq. M. Sc. Thesis, Coll. Sci. Educ., Univ. Salahaddin: 62pp.

Bashê, S.K.R. \& Abdullah, S.M.A. (2010a). Parasitic fauna of spiny eel Mastacembelus mastacembelus from Greater Zab river in Iraq. Iran. J. Vet. Res., Shiraz Univ., 11(1), Ser. 30: 18-27.

Bashê, S.K.R. \& Abdullah, S.M.A. (2010b). The ecology of Mastacembelocleidus heteranchorus (Monogenetic trematode) parasitizing gills of Mastacembelus mastacembelus from Greater Zab river, Kurdistan region- Iraq. J. Duhok Univ., 13(1): 139-143.

Bilal, E.F. (2016). Effect of parasitic infections on some haematological and biochemical parameters in Silurus triostegus from Greater Zab river, Kurdistan region, Iraq. M. Sc. Thesis, Coll. Educ, Univ. Salahaddin: 87pp.

Coad, B.W. (2010). Freshwater fishes of Iraq. Pensoft Publ., Sofia: 274pp. + 16pls. www.briancoad.com.

EOL (2019). Encyclopedia of Life on-line database, http//www.eol.org. (Accessed 4 October 2019).

Esmaeel, H.M. (2018). Effect of environmental pollutants on ectoparasites in three types of Tigris fishes. M. Sc. Thesis, Coll. Educ. Women, Univ. Tikrit: 90pp. (In Arabic).

Fattohy, Z.I. (1975). Studies on the parasites of certain teleostean fishes from the river Tigris, Mosul, Iraq. M. Sc. Thesis, Coll. Sci., Univ. Mosul: 136pp.
Fricke, R.; Eschmeyer, W.N. \& Van der Laan, R. (Eds.) (2019). Eschmeyer's Catalog of Fishes: Genera, Species, References. http://researcharchive.calacademy.org/rese arch/ ichthyology/ catalog/fishcatmain.asp. Electronic online version (updated 3 September 2019).

GBIF (2019). Global Biodiversity Information Facility, on-line database, http://www.gbif.org. (Accessed 4 October 2019).

Gusev, A.V. (1985). Parasitic metazoans: Class Monogenea. In: Bauer, O.N. (ed.). Key to the parasites of freshwater fish fauna of the U.S.S.R. Nauka, Leningrad, 2: 1-424pp. (In Russian).

Hammood, N.W. (2017). Investigation of some parasitic and bacterial infections in some fish species of Tigris river at Baghdad city. M. Sc. Thesis, Coll. Sci., Univ. Tikrit: 141pp. (In Arabic).

Herzog, P.H. (1969). Untersuchungen über die parasiten der süßwasserfische des Irak. Arch. Fischereiwiss., 20(2/3): 132-147.

Jori, M.M. (1998). Study of the parasites of two mugilid fish species and the effect of some on the blood parameters. M. Sc. Thesis, Coll. Agric., Univ. Basrah: 136pp. (In Arabic).

Jori, M.M. (2006). Parasitic study on the Asian catfish Silurus triostegus (Heckel, 1843) from Al-Hammar marshes, Basrah, Iraq. Ph. D. Thesis, Coll. Educ., Univ. Basrah: 192pp.

Jori, M.M. \& Mohamad, E.T. (2008). The effect of Hamatopeduncularia sp. and Caligus sp. on some blood parameters of Arius bilineatus (Val., 1840). Mar. Mesopot., 23(2): 269-277. 
Mhaisen \& Abdul-Ameer/ Basrah J. Agric. Sci., 32(Spec. Issue 2): 45-62, 2019

Kadhim, A.H. (2009). Disease agents of four fish species in Basrah province. M. Sc. Thesis, Coll. Agric., Univ. Basrah: 102pp. (In Arabic).

Khamees, N.R.; Al-Salim, N.K. \& Kadhim, A.H. (2012). Ancyrocephalus polymorphus Gussev, 1955 (Monogenea: Ancyrocephalidae) as additional record to the parasitic fauna of fishes of Iraq. Basrah J. Agric. Sci., 25(2): 84-88. (In Arabic).

Kritsky, D.C.; Khamees, N.R. \& Ali, A.H. (2013). Ligophorus spp. (Monogenoidea: Dactylogyridae) parasitizing mullets (Teleostei: Mugiliformes: Mugilidae) occurring in fresh and brackish waters of the Shatt Al-Arab river and estuary in southern Iraq, with the description of $L$. sagmarius $\mathrm{sp}$. $\mathrm{n}$. from the greenback mullet Chelon subviridis (Valenciennes). Parasitol. Res., 112: 4029-4041.

Kritsky, D.C.; Pandey, K.C.; Agrawal, N. \& Abdullah, S.M.A. (2004). Monogenoids from the gills of spiny eels (Teleostei: Mastacembelidae) in India and Iraq, proposal of Mastacembelocleidus gen. n., and status of the Indian species of Actinocleidus, Urocleidus anHaplocleidus (Monogenoidea: Dactylogyridae). Fol. Parasitol., 51: 291-298.

Lim, H.S.; Timofeeva, T.A. \& D. I. Gibson, D.I. (2001). Dactylogyridean monogeneans of the siluriform fishes of the Old World. Syst. Parasitol., 50: 159-197.

Mansor, N.T.; Falah, A.B.; Al-Jawda, J.M. \& Asmar, K.R. (2012). Histopathological study of some Tigris river fish which infected by parasites. Iraqi J. Vet. Med., 36(1): 33-42 (In Arabic).

Mhaisen, F.T. (2019). Index-catalogue of parasites and disease agents of fishes of
Iraq. (Unpublished: mhaisenft@yahoo.co.uk).

Mhaisen, F.T. \& Abdul-Ameer, K.N. (2013). Checklists of Gyrodactylus species (Monogenea) from fishes of Iraq.

Mhaisen, F.T. \& Abdul-Ameer, K.N. (2014). Checklists of diplozoid species (Monogenea) from fishes of Iraq. Bull. Iraq Nat. Hist. Mus., 13(2): 95-111.

Mhaisen, F.T. \& Abdul-Ameer, K.N. (2019). Checklists of Dactylogyrus species (Monogenea) from fishes of Iraq. Biol. Appl. Environ. Res., 3(1): 1-36.

Mhaisen, F.T.; Al-Rubaie, A.L. \& Al-Sa'adi, B.A. (2015). Monogenean parasites of fishes from the Euphrates river at $\mathrm{Al}$ Musaib city, mid Iraq. Am. J. Biol. Life Sci., 3(2): 50-57.

Mhaisen, F.T.; Balasem, A.N.; Al-Khateeb, G.H. \& Asmar, K.R. (1997). Recording of five monogenetic trematodes for the first time from fishes of Iraq. Abstr. $14^{\text {th }}$ Sci. Conf., Iraqi Biol. Soc., Najaf: 11-13 March 1997.

Mhaisen, F.T.; Balasem, A.N.; Al-Khateeb, G.H. \& Asmar, K.R. (2003). Recording of five monogenetic trematodes for the first time from fishes of Iraq. Bull. Iraq Nat. Hist. Mus., 10(1): 31-38.

Mohammed, H.J. (2017). Parasitic fauna of some fish species from Diyala river in Diyala province. M. Sc. Thesis, Coll. Educ. Pure Sci., Ibn Al-Haitham, Univ. Baghdad: 122pp. (In Arabic).

MonoDb (2019). MonoDb.org. A web-host for the Monogenea. (Accessed 4 October 2019). 
Mhaisen \& Abdul-Ameer/ Basrah J. Agric. Sci., 32(Spec. Issue 2): 45-62, 2019

Owaied, Y.H.; Mahmoud, A.J. \& Esmaeel, H.M. (2018). Effect of environmental pollutants on ectoparasites on three types of Tigris fish. IOSR J. Environ. Sci., Toxicol. Food Technol. (IOSR-JESTFT), 12(9): 1-8.

Pugachev, O.N.; Gerasev, P.I.; Gussev, A.V.; Ergens, R. \& Khotenowsky, I. (eds.) (2009). Guide to Monogenoidea of freshwater fish of Palaearctic and Amur regions. Ledizioni Ledi Publ., Milano: $567 \mathrm{pp}$.

Rahemo, Z.I.F. \& Al-Neemi, B.H.S. (1999). Observations on the histopathology caused by some parasites of the freshwater fish, Silurus glanis L. Riv. Parassitol., 16(60), No. 3: 227-235.
Rahemo, Z.I.F. \& Al-Niaeemi, B.H.S. (2001). Parasites of Silurus glanis inhabiting Tigris river passing Mosul city. J. Al-Qadisiya, Pure Sci., 6(3): 116-125. (In Arabic).

Rasheed, R.A.-R. (2016). Parasites of some fishes of Tigris river in Al-Shawwaka region, Baghdad city-Iraq. M. Sc. Thesis, Coll. Educ. Ibn Al-Haitham, Univ. Baghdad: 106pp. (In Arabic).

Shwani, A.A.A. (2009). The parasitic fauna of Asian catfish Silurus triostegus (Heckel, 1843) from Greater Zab river- Kurdistan region- Iraq. M. Sc. Thesis, Coll. Sci. Educ., Univ. Salahaddin: 75pp.

WoRMS (2019). World Register of Marine Species at http://www. marinespecies.org. (Accessed 4 October 2019). 